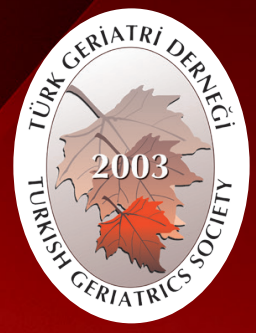

Turkish Journal of Geriatrics

DOI: $10.31086 /$ tjgeri.2019150567

2019;22 (1):9-17

- Eray ATALAY ${ }^{1}$ (D)

- Halil İrahim ERDOĞDU1 (D)

- Bilge Kağan TUR ${ }^{2}$ D

- Lütfiye Seçil DENIZ BALYEN ${ }^{1}$ (D)

- Yavuz KARABAĞ ${ }^{3}$ D

- Sadık ARDIÇ ${ }^{4}$ iD

CORRESPONDANCE

Bilge Kağan TUR

Kafkas University, Faculty of Medicine,

Department of Internal Medicine, Kars, Turkey

Phone: 04742251150

e-mail: kaantur542@gmail.com

Received: 12/12/2018

Accepted: 13/02/2019

Kafkas University, Faculty of Medicine,

Department of Internal Medicine, Kars, Turkey

Ortaköy Public Hospital, Department of Internal

Medicine, Aksaray, Turkey

${ }^{3}$ Kafkas University, Faculty of Medicine,

Department of Cardiology, Kars, Turkey

${ }^{4}$ Koru Hospital, Department of Pulmonary

Medicine and Sleep Disorders, Ankara, Turkey

\section{THE RELATIONSHIP BETWEEN C REACTIVE PROTEIN /ALBUMIN RATIO AND 1-YEAR MORTALITY IN HOSPITALIZED ELDERLY COPD PATIENTS WITH ACUTE EXACERBATION}

\section{Abstract}

Introduction: Chronic obstructive pulmonary disease (COPD) is a leading cause of mortality. C-reactive protein (CRP) is often elevated with acute infective and inflammatory situations. Hypoalbuminemia may be linked to chronic diseases and malnutrition. Here, we investigated the relationship between 1-year mortality and CRP/albumin ratio (CAR) among hospitalized elderly patients with COPD acute exacerbation.

Materials and method: The records of patients who were hospitalized with COPD diagnosis in the internal medicine and chest diseases clinics of Kafkas University Medical Faculty Hospital between January 2014 and May 2017 were retrospectively evaluated to determine whether selected patients had died within 1 year of hospitalization. The patients who died (Group 1) and those who were living (Group 2) were compared in terms of various parameters, especially CAR.

Results: In Group 1, CRP levels were high and albumin levels were significantly lower; the CAR ratio in group 1 was $0.36(0.29-0.64)$, which was significantly elevated, compared with that of Group $2(0.09 ; 0.03-0.27)$. In the multivariate analysis, independent predictors of 1-year mortality were CAR [1.116 (1.025-1.216), $\mathrm{p}=0.011]$, smoking (packs/year) [1.135 (1.082-1.190), $\mathrm{p}<0.05], \mathrm{pH}[0.001(0-0.14)]$, BODE index [1.693 (1.157-2.478)], and FEV1/FVC [0.911 (0.846$0.980)]$. Area under the curve values of CAR for 1-year mortality were significantly higher than the values of both albumin and CRP alone $(p<0.05)$

Conclusion: The CRP/albumin ratio is an independent predictor of 1-year mortality in patients with COPD. More comprehensive prospective studies are needed to confirm this finding.

Keywords: C-Reactive protein; Serum Albumin, Pulmonary Disease, Chronic Obstructive, C-Reactive Protein/analysis

ARAŞTIRMA

\section{AKUT KOAH ATAĞI ILE HASTANEYE YATIRILAN YAŞLI HASTALARDA 1 YIL MORTALITE ILE C REAKTIF PROTEIN/ALBUMIN ORANI ARASINDAKI İLIŞKININ DEĞERLENDİRILMESi}

\section{Öz}

Giriş: Kronik obstruktif akciğer hastalığı (KOAH) mortalitenin önde gelen bir nedenidir. $C$ reaktif protein (CRP) genellikle akut enfektif ve enflamatuar durumlarda artış gösterir. Hipoalbuminemi kronik hastalıklar ve malnurtisyon ile ilişkili olabilmektedir. Bu çalışmada $\mathrm{KOAH}$ akut atak ile hastaneye yatıılan yaşlı hastalarda CRP/albumin oranı (CAO) ile 1 yıllık mortalite arasındaki ilişki araştırılmıştır.

Gereç ve Yöntem: Ocak 2014-Mayıs 2017 tarihleri arasında Kafkas Üniversitesi Tıp Fakültesi iç hastalıkları ve göğüs hastalıkları kliniklerinde $\mathrm{KOAH}$ atak ile yatırılan hastaların kayıtları retrospektif olarak hastane yatışının ilk 1 yılı içerisinde hayatta olup olmadıkları araştırılarak değerlendirildi. Ölen hastalar grup 1, sağ kalan hastalar grup 2 olarak ayrıldı ve başta CAO olmak üzere parametreler karşılaştırıldı.

Bulgular: Grup 1'de CRP seviyesi yüksek, albümin seviyesi anlamlı olarak düşüktü ve CAO Grup 1'de 0.36 (0.29-0.64) olup Grup 2'den 0,09 (0.03-0.27) anlamlı olarak daha yüksekti. Yapılan multivariyent analizde 1 yıllık mortalitenin bağımsız prediktörleri CAO [1.116(1.0251.216) $\mathrm{p}=0.011]$, sigara içimi (paket/yı) [1.135 (1.082-1.190) $\mathrm{p}<0.05], \mathrm{pH}$ [0.001(0-0.14)], BODE [1.693 (1.157-2.478)], FEV1/FVC [0.911(0.846-0.980)] olarak bulundu. Bir yıllık mortalite için CAO'nun AUC değerleri hem albümin hem de CRP'nin tek başına olan değerlerinden anlamlı yüksekti $(P<0.05)$.

Sonuç: CRP/albümin oranı KOAH'ı hastalarda 1 yıllık mortalitenin bağımsız bir prediktörüdür. Bu bulgunun doğrulanması için daha kapsamlı prospektif çalışmaların planlanması gereklidir.

Anahtar sözcükler: C reaktif protein; Kronik Obstruktif Akciğer Hastalığı; C reaktif protein/ albumin oranı 


\section{INTRODUCTION}

Chronic obstructive pulmonary disease (COPD) is a frequent disease characterized by persistent respiratory symptoms and airway limitation. COPD is a leading cause of morbidity and mortality worldwide, as reported by the Global Initiative for Chronic Obstructive Lung Disease (GOLD) 2018 (1). According to World Health Organization (WHO) data, more than 65 million people had moderate and severe COPD in 2005; additionally, more than 3 million deaths were caused by COPD (2). Acute exacerbation of COPD is often associated with deterioration of respiratory symptoms and requires hospitalization, which is an important contributor to the mortality of COPD patients. Individual risk assessment in patients admitted to the hospital may be especially useful in terms of prognosis. The presence of links among biomarkers is frequently referenced during admission and prognosis may be useful in determining high-risk patients.

Chronic obstructive pulmonary disease is a multifactorial disease. Modifiable risk factors (e.g., smoking, occupational exposure, and air pollution) as well as non-changeable risk factors (e.g., aging and bronchial hyperreactivity) play roles in the etiology of COPD. Smoking is the most important risk factor. Mucus accumulation, bronchial fibrosis, and local inflammation associated with these risk factors cause permanent damage to the lungs. Patients with COPD often exhibit low-grade systemic inflammation. This condition is evidenced by changes in tumor necrosis factor (TNF) alpha, Interleukin (IL)-6, and C-reactive protein (CRP) levels and the presence of leukocytosis in patients. Systemic inflammation plays an important role in the pathogenesis of COPD, disease progression, and mortality (3).

C-reactive protein is an acute phase protein and is widely used in the clinical evaluation of patients. In addition to CRP, serum albumin levels may also be important in prognosis as a negative acute phase reactant whose level is negatively correlated with the severity of the inflammatory response induced by infection in critically ill patients. Therefore, serum albumin may decrease, whereas CRP may increase, during acute exacerbation of COPD. CRP/albumin ratio (CAR) is positively correlated with infection, as high rates indicate more severe inflammation. Previous studies have shown an association between 90-day mortality and CAR in patients with sepsis. However, no such studies have been performed in patients with COPD. We investigated whether there is a relationship between CAR during hospitalization and 1-year mortality in patients hospitalized for acute exacerbation of COPD.

\section{MATERIALS AND METHOD}

The records of patients who were admitted to the internal medicine, emergency and chest diseases clinics of Kafkas University Medical Faculty Hospital and hospitalized with COPD diagnosis, during the period between January 2014 and May 2017, were retrospectively evaluated. For this purpose, the hospital database was primarily used to identify patients who were hospitalized for COPD. The following characteristics of the patients were evaluated: age, gender, duration of disease, smoking status (smokers who smoking currently and those who smoked before were treated as smokers and those who never smoked were considered non-smokers and the amount of cigarettes they smoked was calculated as package/year), comorbid diseases, patient's history of invasive and/or noninvasive mechanical ventilation requirement, BODE index calculated accordingly (4), duration of hospitalization, physical examination at admission, laboratory data (complete blood count(CBC), CRP, CAR, and biochemistry) arterial blood gas, posteroanterior chest radiograph, and echocardiography on admission. The 6-minute walk test and respiratory function test results recorded at the time of the mostrecenthospitalization. The frequencies of admission to hospital and emergency department were searched, new hospitalizations were identified for patients. All patients who died within 1 year after hospitalization were recorded. For the diagnosis of COPD, post-bronchodilator respiratory function test result was required to be below $70 \%$. Patients with any of the following conditions were excluded from the study: need for intensive care, incompatible respiratory function test, pneumonic infiltrates on 
chest X-ray, decompensated heart failure, additional disease disrupting the general condition. Patients with missing data data in any of the parameters were excluded from the study. We investigated whether the parameters that could predict mortality, particularly CAR, were significantly different between the group with 1-year mortality (Group 1) and the group in which patients remained living at the end of 1 year (Group 2).

\section{Statistical analysis}

Statistical analyses were performed using the MedCalc and SPSS 22.0. Normality of the data was analyzed using the Kolmogorov-Smirnov test. Continuous variables with normal distribution are expressed as mean ( \pm standard deviation) values and were compared using the independent t-test. Continuous data without normal distribution were presented as median interquartile ranges (25-75 percentiles) values and were compared using the Mann-Whitney $U$ test. Categorical variables are expressed percentages and were compared using Fisher's exact test or the $x$ 2-test. The risk factors for 1-year all-cause mortality were analyzed using multivariate Cox proportional hazard analysis was performed with variables that showed statistically significant associations with mortality in the univariate analyses. Multicollinearity between CAR and its components (CRP and albumin) was assessed by Eigen value and condition index. Linearity was tested by interacting with the logarithmic transformation of each parameter itself. The receiver operating characteristic (ROC) curve was utilized to derive the best cut-off values of the CAR for predicting all-cause mortality. The method proposed by DeLong et al. was then used to compare the ROC curves of CAR, CRP, albumin, and NLR for predicting all-cause mortality. $P$ values $<0.05$ were considered statistically significant.

\section{RESULTS}

In total, 1592 patients who were hospitalized with COPD were evaluated retrospectively. Two hundred thirty-two patients were excluded from the study because they were admitted directly to the intensive care unit; 94 patients did not have respiratory function test results appropriate for COPD, 523 of the patients respiratory function test results were missing, so these patients were excluded. 109 patients were not included in the study because of obvious pneumonic infiltration on chest X-ray, 41 patients did not include in the study because of the presence of decompensated heart failure and uncontrolled diabetes mellitus; 310 patients with missing at least one of the following parameters were missing: labaratory results, patient history and physical examination were excluded from the study. The remaining 283 patients who met all the criteria were included in the study. Sixty-three of these patients died within 1 year after hospitalization. The study flowchart is shown in Figure 1.

The mean age for all cases was $70.83 \pm 8.96$ years; this was not significantly different between the two groups ( $p>0.05$ ). In total, 152 of the patients were male (53\%); 131 of them were female (47\%). There was no significant difference between the two groups in by gender $(p=0.392)$.

The proportion of comorbid diseases were similar between groups 1 and 2 consisting hypertension, diabetes and coronary artery disease. Smoking rates were similar, but packs/year of smoking in group 1 was significantly longer than group $2(p<0.01)$. Pulse rate and blood pressure level were similar, left ventricular systolic functions at the time of echocardiography were also similar ( $p>0.05)$. Initial respiratory rate was significantly higher in group $1 \quad(p<0.05)$, whereas oxygen saturation was lower in group $1(p<0.01)$.

White blood cells (WBCs), creatinine, lactate dehydrogenase $(\mathrm{LDH})$, and $\mathrm{pCO}_{2}$ were significantly higher in Group 1; hemoglobin and total protein $(p<0.05)$, as well as $\mathrm{pH}, \mathrm{pO}_{2^{\prime}}$ and $\mathrm{FEV1/FVC}$ ratio $(p<0.01$ for all three) were significantly lower.

The rate of re-hospitalization within 1 year was higher in Group 2 ( $p>0.05)$. Body mass index was significantly lower in Group 1 and the duration of hospitalization was significantly longer $(p<0.01)$.

In Group 1, the ratio of patients who had MMRC dyspnea score 3-4 was higher than that in group 2, but not statistically significant ( $p>0.05$ ). Six-minute walking test results were significantly lower in group 1 , whereas BODE index was significantly higher $(p<0.01)$. 
In Group 1, CRP levels were higher, whereas albumin levels were significantly lower $(p<0.05)$. CAR was $0.36(0.29-0.64)$ and $0.09(0.03-0.27)$ in groups 1 and 2, respectively; Group 1 had significantly higher CAR levels than those of group 2 (Table 1) $(p<0.01)$.

To identify the independent predictors of 1 -year mortality, multivariate cox regretion analyses with a stepwise backward model were performed using the variables that showed marginal association with 1-year mortality in the univariate analyses; these variables included.

In the multivariate analysis, independent predictors of 1-year mortality were: cigarette smoking time (packs/year) [1.135 (1.082-1.190), $\mathrm{p}<0.001], \mathrm{pH}$ [0.001 (0-0.14), $p<0.001]$, BODE [1.693 (1.157-2.478), $\mathrm{p}=0.007], F E V 1 / F V C[0.911(0.846-0.980), p=0.013]$, and CAR [1.116 (1.025-1.216), $\mathrm{p}=0.011$ ] (Table 2).

Receiver operating characteristric curve results of 1-year mortality were as follows: for CAR (area under the curve (AUC) $0.639,95 \% \mathrm{Cl} 0.569-0.709$ ), for CRP (AUC 0.599, 95\% Cl 0.524-0.675), and for albumin (AUC 0.593, 95\% Cl 0.514-0.673) (Figure 2). The AUC value of CAR was significantly higher than that of either albumin or CRP alone $(p<0.05)$. Its sensitivity for predicting death was $64.71 \%$, while its specificity was $59.53 \%$ with the measured CAR cut-off value (0.639). BODE index (AUC 0.678, 95\% Cl 0.619-0.733), which has been identified as a successful index in predicting mortality in COPD, did not have a statistically significant advantage over CAR (AUC 0.639, 95\% Cl $0.569-0.709)$ ( $p>0.05)$.

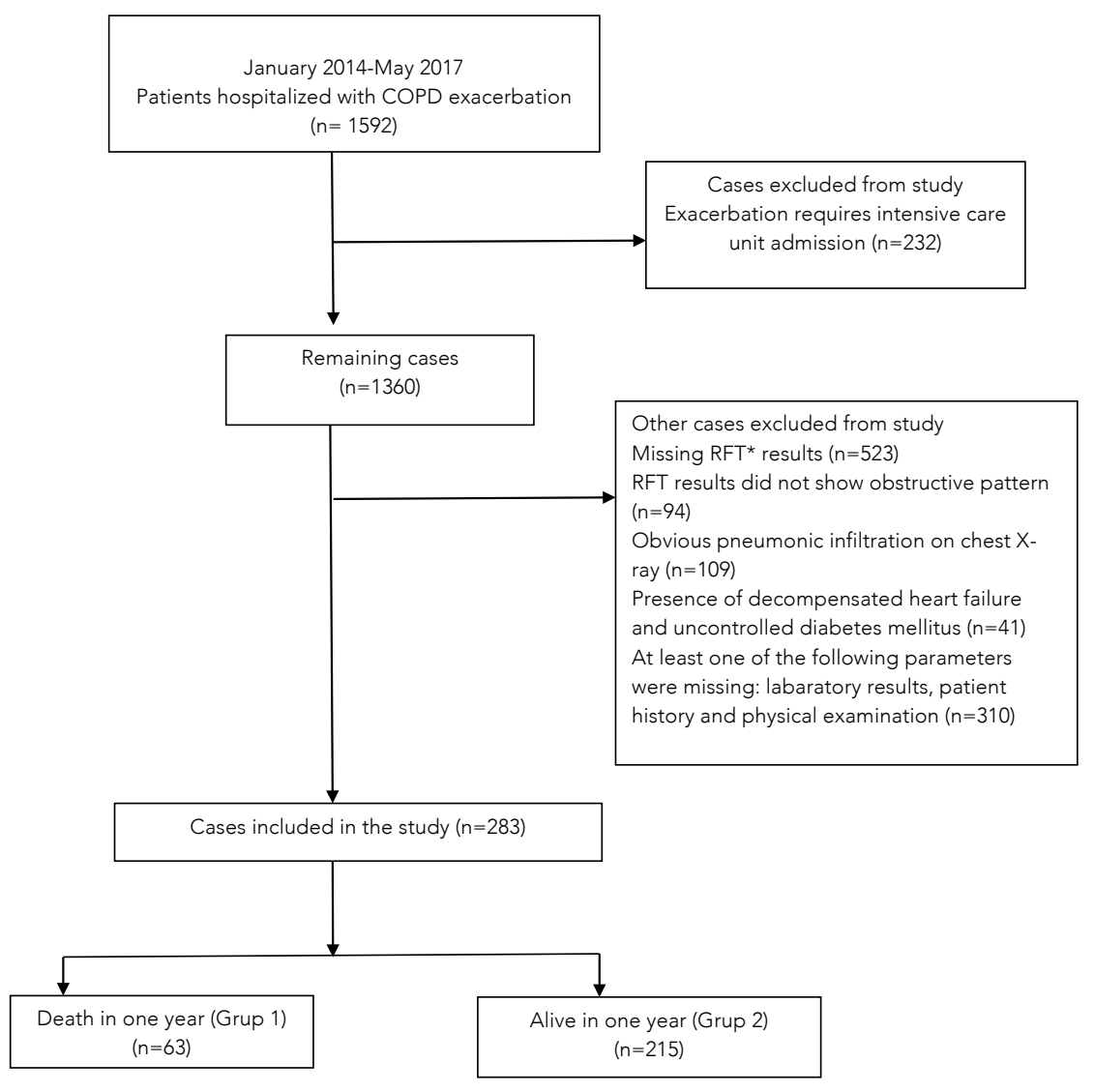

${ }^{\star R F T}$ : Respiratory function test

Figure 1. Retrospective study patient inclusion procedure (study flow chart). 
Table 1. Comparison of all parameters between living and deceased groups.

\begin{tabular}{|c|c|c|c|c|c|c|c|c|}
\hline \multirow{2}{*}{ Characteristics } & & \multicolumn{7}{|c|}{ All-Cause mortality } \\
\hline & & \multicolumn{2}{|r|}{$\begin{array}{r}\text { All patients } \\
(\mathrm{n}: 283)\end{array}$} & \multicolumn{2}{|c|}{$\begin{array}{r}\text { Survived patients } \\
(n: 215)\end{array}$} & \multicolumn{2}{|c|}{$\begin{array}{r}\text { Non-surviving } \\
(\mathrm{n}: 63) \\
\end{array}$} & $\mathrm{F}$ \\
\hline Age (year) & & 70.8 & \pm 9.0 & 70.7 & \pm 9.2 & 71.2 & \pm 8.3 & 0.810 \\
\hline Female gender. n (\%) & & 131 & $(47.0)$ & 96 & $(45.5)$ & 35 & $(51.5)$ & 0.392 \\
\hline Hypertension. n (\%) & & 133 & $(47.0)$ & 98 & $(45.6)$ & 35 & $(51.5)$ & 0.397 \\
\hline Diabetes n (\%) & & 59 & $(20.8)$ & 43 & $(20.0)$ & 16 & $(23.5)$ & 0.533 \\
\hline CAD (\%) & & 64 & $(22.6)$ & 46 & $(21.4)$ & 18 & $(26.5)$ & 0.384 \\
\hline Smoking n (\%) & & 37 & $(13.1)$ & 28 & $(13.0)$ & 9 & $(13.2)$ & 0.964 \\
\hline Pack/year of smoking & & 22 & \pm 7.7 & 20 & \pm 7.0 & 30 & \pm 4.9 & $<0.001$ \\
\hline Re-hospitalization in 1 year $\mathrm{n}(\%)$ & & 203 & $(71.7)$ & 158 & $(73.5)$ & 45 & $(66.2)$ & 0,244 \\
\hline $\mathrm{SBP} H g(\mathrm{~mm} \mathrm{Hg})$ & & 119.7 & \pm 12.5 & 119.2 & \pm 11.0 & 121.1 & \pm 16.5 & 0.571 \\
\hline Heart rate (bpm) & & 85.0 & \pm 41.3 & 82.6 & \pm 13.0 & 92.7 & \pm 81.4 & 0.796 \\
\hline Respiration Rate (per min) & & 20.6 & \pm 8.4 & 20.0 & \pm 6.1 & 22.6 & \pm 13.0 & 0.054 \\
\hline Saturation (\%) & & 90.5 & \pm 7.6 & 91.4 & \pm 6.1 & 87.3 & \pm 10.7 & $<0.001$ \\
\hline WBC (/1000) & & 8.7 & \pm 5.6 & 8.3 & \pm 5.5 & 9.9 & \pm 5.5 & 0.002 \\
\hline Neutrophil (/1000) & & 7.3 & \pm 4.0 & 7.4 & \pm 4.1 & 7.1 & \pm 3.6 & 0.872 \\
\hline Hemoglobin (g/dL) & & 13.4 & \pm 2.8 & 13.6 & \pm 2.6 & 12.7 & \pm 3.1 & 0.040 \\
\hline Platelet (/1000) & & 237 & $176-309$ & 241 & 184-303 & 227 & $148-316$ & 0.206 \\
\hline Glucose (mg/dL) & & 121 & $100-163$ & 120 & 100-159 & 121 & $103-170$ & 0.611 \\
\hline Creatinine $(\mathrm{mg} / \mathrm{dL})$ & & 1.0 & $0.7-1.5$ & 1.0 & $0.7-1.4$ & 1.1 & $0.8-1.8$ & 0.051 \\
\hline $\mathrm{LDH}(\mathrm{U} / \mathrm{L})$ & & 243 & $202-325$ & 239 & 199-305 & 278 & $223-463$ & $<0.001$ \\
\hline CRP (mg/dL) & & 3.8 & $1.2-9.0$ & 3.2 & $1.0-8.3$ & 6.4 & $1.9-11.2$ & 0.013 \\
\hline Albumin (gr/dL) & & 3.6 & \pm 0.6 & 3.6 & \pm 0.5 & 3.4 & \pm 0.6 & 0.020 \\
\hline CAR & & 0.2 & $0.03-0.32$ & 0.1 & $0.02-0.26$ & 0.4 & $0.28-0.63$ & $<0.001$ \\
\hline Total Protein (gr/dL) & & 6.9 & \pm 0.9 & 7.0 & \pm 0.9 & 6.6 & \pm 0.9 & 0.004 \\
\hline $\mathrm{pH}$ & & 7.4 & \pm 0.1 & 7.4 & \pm 0.1 & 7.3 & \pm 0.1 & $<0.001$ \\
\hline $\mathrm{PCO} 2(\mathrm{~mm} \mathrm{Hg})$ & & 41.4 & \pm 12.3 & 39.9 & \pm 11.3 & 45.9 & \pm 14.0 & $<0.001$ \\
\hline $\mathrm{PO} 2(\mathrm{~mm} \mathrm{Hg})$ & & 56.4 & \pm 19.8 & 59.8 & \pm 18.1 & 45.6 & \pm 21.3 & $<0.001$ \\
\hline Duration of Hospitalization, day & & 6.8 & \pm 4.6 & 5.0 & \pm 2.4 & 7.0 & \pm 2.3 & $<0.001$ \\
\hline Intubation & & 13 & \pm 4.7 & 8 & $(3.8)$ & 5 & $(7.6)$ & 0.199 \\
\hline Noninvasive Mechanical Ventilation & & 24 & (8.6) & 17 & $(8.0)$ & 7 & $(10.6)$ & 0.507 \\
\hline Left Ventricular Ejection Fraction (\%) & & 67.9 & \pm 6.3 & 67.9 & \pm 6.1 & 67.7 & \pm 7.3 & 0.747 \\
\hline Ratio of FEV1 to FVC & & 54.7 & \pm 4.9 & 55.5 & \pm 4.3 & 52.0 & \pm 5.5 & $<0.001$ \\
\hline FEV1 & & 1.6 & $1.0-2.5$ & 1.8 & $1.1-2.5$ & 1.5 & $0.8-2.4$ & 0.063 \\
\hline Percentage of Predicted FEV1 & & 42.8 & 6.0 & 43.7 & 5.4 & 40.2 & 7.0 & $<0.001$ \\
\hline \multirow{4}{*}{ mMRC score } & 1.00 & 10 & (3.5) & 9 & $(4.2)$ & 1 & $(1.5)$ & 0.075 \\
\hline & 2.00 & 42 & $(14.8)$ & 34 & $(15.8)$ & 8 & (11.8) & \\
\hline & 3.00 & 213 & $(75.3)$ & 161 & $(74.9)$ & 52 & $(76.5)$ & \\
\hline & 4.00 & 18 & $(6.4)$ & 11 & $(5.1)$ & 7 & $(10.3)$ & \\
\hline $\mathrm{BMI}\left(\mathrm{kg} / \mathrm{m}^{2}\right)$ & & 23.1 & \pm 1.2 & 23.6 & \pm 0.8 & 21.5 & \pm 0.8 & $<0.001$ \\
\hline Six Minutes Walking Test (m) & & 325.8 & \pm 41.2 & 335.6 & \pm 38.3 & 294.8 & \pm 34.0 & $<0.001$ \\
\hline BODE & & 4.8 & \pm 1.0 & 4.6 & \pm 1.0 & 5.3 & \pm 0.9 & $<0.001$ \\
\hline
\end{tabular}

CAD: Coronary Artery Disease, SBP: Systolic Blood Pressure, WBC: White Blood Cell, LDH: Lactate Dehydrogenase, CRP: C-reactive protein, CAR: CRP/Albumin Ratio, FEV: Forced Expiratory Volume, FVC: Forced Vital Capacity, MMRC: modified Medical Research Council, BODE: Body-mass index, Airflow Obstruction, Dyspnea, and Exercise. 
Table 2. Independent predictors of 1-year mortality in multivariate analysis.

\begin{tabular}{|c|c|c|c|c|c|c|}
\hline \multirow[t]{2}{*}{ Characteristics } & \multicolumn{3}{|c|}{$\begin{array}{r}\text { Univariate analysis of predictors 1-year } \\
\text { mortality }\end{array}$} & \multicolumn{3}{|c|}{$\begin{array}{r}\text { Multivariate analysis of predictors 1-year } \\
\text { mortality }\end{array}$} \\
\hline & $\mathrm{p}$ & Hazard ratio & 95\% C.I. & $\mathrm{p}$ & Hazard ratio & $95 \%$ C.I. \\
\hline Smoking & $<0.001$ & 1.179 & $1.138-1.223$ & $<0.001$ & 1.135 & 1.082-1.190 \\
\hline $\mathrm{Ph}$ & $<0.001$ & 0.001 & $0.000-0.004$ & $<0.001$ & 0.001 & 0.000-0.014 \\
\hline FEV1/FVC & $<0.001$ & 0.871 & $0.830-0.915$ & 0.013 & 0.911 & 0.846-0.980 \\
\hline BODE & $<0.001$ & 1.891 & $1.458-2.451$ & 0.007 & 1.693 & $1.157-2.478$ \\
\hline CRP/Albumin ratio & $<0.001$ & 1.132 & $1.022-1.254$ & 0.011 & 1.116 & $1.025-1.216$ \\
\hline
\end{tabular}

FEV: Forced Expiratory Volume, FVC: Forced Vital Capacity, BODE: Body-mass index, Airflow Obstruction, Dyspnea, and Exercise, CRP: C-reactive protein

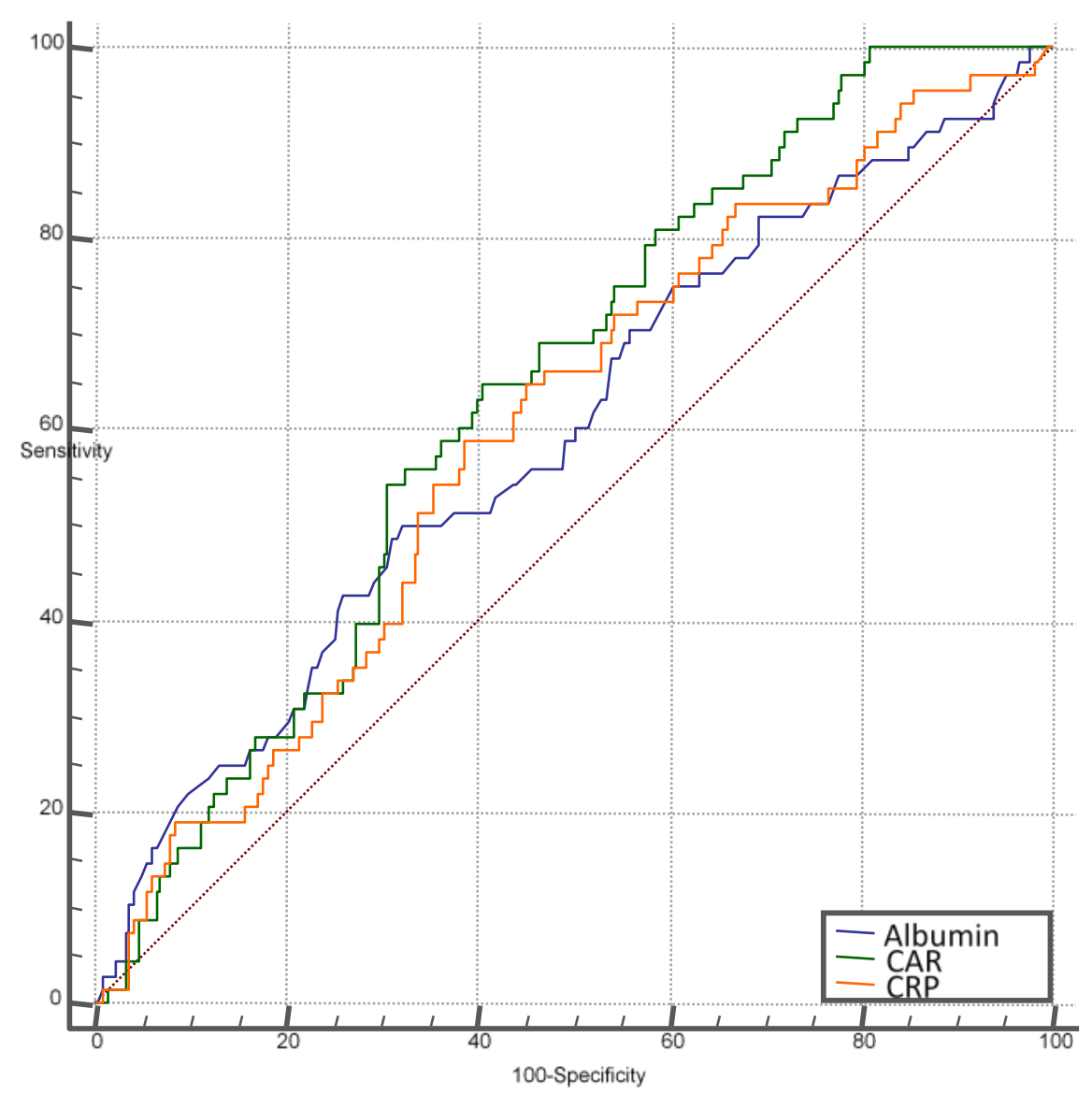

Figure 2. ROC curves of C-reactive protein (CRP), albumin, and CRP/Albumin Ratio. 


\section{DISCUSSION}

Forced expiratory volume 1 is the most important indicator of the severity of airway obstruction, but its predictive value for mortality is poor. Because of the wide range in airway stenosis, it is better to predict mortality in COPD patients with other clinical variables that can be easily measured, compared with FEV1. MMRC dyspnea score, exercise capacity, and $\mathrm{BMI}$ are the most commonly used variables. In addition, it is increasingly common to predict mortality by means of with various biomarkers. Multicomponent methods are also used for this purpose (e.g., BODE index). Conflicting results have been reported regarding which of these methods are more valuable (4-6).

C-reactive protein elevation is a nonspecific indicator of systemic inflammation and is associated with an increased risk of mortality in patients with COPD (7). CRP is not an important predictor of death when evaluated with other predictors, such as BMI, expected FEV1, MMRC dyspnea score, 6-minute walking test, and BODE index in patients with moderate and severe COPD (8).

Ranzani et al. examined whether serum CRP and CAR as indicators of residual inflammation are risk factors for mortality during the intensive care unit discharge period and mortality within 90 days after intensive care unit discharge, among 334 patients who spent a minimum of 72 hours in the intensive care unit with diagnoses of sepsis and septic shock. They found serum CRP and CAR to be independent risk factors for mortality (9).

In our study showed that increased CAR was significantly correlated with 1 year mortality in hospitalized COPD patients. Smoking duration (packs/year), pH, FEV1/FVC ratio, and BODE index were important, in addition to $C A R$, as independent predictors of 1-year mortality, as shown by multivariant analyses.

In our study, ROC curve analysis was used to determine the cut-off value. For 1-year mortality, ROC curves were generated for CAR $(0.639,95 \% \mathrm{Cl}$
0.569-0.709), CRP $(0.599,95 \% \mathrm{Cl} 0.524-0.675)$, and albumin $(0.593,95 \% \mathrm{Cl} 0.514-0.673)$. AUC values of CAR were significantly higher than those of both albumin and CRP alone. The sensitivity of death prediction was $64.71 \%$; its specificity was $59.53 \%$ with the measured cut-off value of CAR (0.639).

Fairclough et al. evaluate emergency department admissions found a strong correlation between modified early warning score (MEWS) and CAR. The increase in CAR was less sensitive with respect to total mortality than MEWS, but was more valuable in the elderly, especially in cases of acute exacerbation of chronic disease (10).

There have been COPD studies in which only the CRP component of CAR is evaluated. At several studies both CAR parameters were investigated among patients who were admitted to the emergency department.

In our study, the average age of patients with COPD was 70 years, and the relationship between CAR and mortality (due to advanced age and acute exacerbation of chronic disease) was consistent with that identified by Fairclough, et al.

A meta-analysis in COPD patients showed that CRP elevation is especially significant in late mortality (11). High CRP and neutrophil levels, as well as low eosinophil levels have been shown to be poor prognostic factors (12). In our study, high CRP levels, reduced albumin levels and FEV1/FVC, as well as elevation of WBCs, were significant in group 1; notably, there was no significant difference for neutrophil count. Cachexia and reduction of muscle mass, which are systemic manifestations of COPD, were associated with increased mortality (13). Studies have shown that low BMI is a predictor of mortality in patients with COPD $(14,15)$. In our study, BMI in Group 1 was significantly lower than that in group 2. While CRP increase is typically associated with acute infectious and inflammatory events, hypoalbuminemia is associated with chronic diseases. Moreover, it may be associated 
with malnutrition. Therefore, CAR may have a higher predictive value than either CRP elevation or hypoalbuminemia alone. In our study, CAR was significantly higher than CRP or albumin levels alone.

Several parameters have been studied to determine prognosis in COPD patients. One of these is the BODE index. Marin et al. reported a significant correlation between BODE index and survival. It was found more valuable than FEV1 in predicting outcomes (15).

Exercise capacity is also an independent risk factor for predicting mortality in COPD. It was reported that severe predominantly male COPD patients exhibited progressive reduction of 6-minute walking distance; this reduction is independent from changes in FEV1. Therefore, the 6-minute walk test is a better predictor of mortality than FEV1 (16). In our study, an increased BODE index was an independent risk factor for prediction of mortality. Interestingly, our study sample did not have a predominantly male population. The prevalence of COPD in women has been attributed to the widespread biomass exposure of women in Kars.

Mortality in COPD was assessed by studies; there are reports suggesting parameters such as FEV1, IC/TLC, 6-minute walking test, maximum oxygen consumption, BMI, MMRC dyspnea score, BODE index, fibronectin/CRP ratio, echocardiography (17). In our study, low BMI and severe airway obstruction, as well as MMRC dyspnea score, were found to be significantly different between the deceased and the living group. The frequency of admission to the hospital did not differ between the two groups. This difference was attributed to the relatively low follow-up of the deceased group.

In our study, we found that oxygen partial pressure, oxygen saturation, and $\mathrm{pH}$ were significantly lower, while carbon dioxide and obstruction were significantly higher in the deceased group. WBCs, creatinine, and LDH levels of the deceased group were also significantly higher, while hemoglobin, albumin, and total protein levels were significantly lower. We found that the deceased group had a higher packs/year tobacco consumption than the living group, and that the deceased group had longer hospitalization durations than the living group. Although the MMRC dyspnea score was higher in the deceased group, it was not significantly different. Similarly, there was no difference between the two groups in terms of the frequency of re-hospitalization.

In our study, cigarette use, low FEV1/FVC and BODE index, were independent predictors of mortality. These findings were consistent with current literature. Furthermore, in our study, CAR could be a more important marker of mortality rather than the CRP level. In the current literature, there is no similar study regarding patients with COPD. We have shown that 1-year mortality, estimated with CAR in COPD patients, can be more practical and can predict in a manner similar to that of the BODE index; however, the BODE index is more laborious and is not easy to perform in each patient. The main limitations of our study are as follows: the retrospective character of the study was the limiting aspect of our study. It should be supported by prospective studies. Our study consisted of data from single center. Moreover, for CRP and albumin, only the first laboratory values of the patient's hospital intake assessment were considered and the patients' exact causes of death were unknown.

In conclusion, we speculate that CAR may be an important predictor in determining the mortality of COPD, in combination with other parameters. With the help of randomized controlled, prospective, well-designed studies of this patient group, we believe that CAR can take its place in the clinical setting as a reliable prognostic marker. 


\section{REFERENCES}

1. Vogelmeier CF, Criner GJ, Martinez FJ, et al. Global Strategy for the Diagnosis, Management and Prevention of Chronic Obstructive Pulmonary Disease 2018 Report. Global Initiative for Chronic Obstructive Lung Disease (GOLD) 2018;1:12-3. [Internet] Available from: https://goldcopd.org/wpcontent/uploads/2017/11/GOLD-2018-v6.0-FINALrevised-20-Nov_WMS.pdf. Accessed: 18.9.2018.

2. WHO. World health statistics 2008. World Health Organization Library Cataloguing in Publication Data. 2008;1:29-30. [Internet] Available from:http:// www.who.int/whosis/whostat/EN_WHS08_Full. pdf?ua=1. Accessed: 22.9.2018.

3. Leuzzi G, Galeone C, Taverna F, Suatoni P, Morelli D, Pastorino U.C-reactive protein level predicts mortality in COPD: a systematic review and meta-analysis Eur Respir Rev 2017;26:2-14. (PMID:28143876).

4. Celli BR. Predictors of mortality in COPD. Respir Med 2010;104:773-9. (PMID:20417082).

5. Lomholt FK, Laulund AS, Bjarnason NH, et al. Metaanalysis of routine blood tests as predictors of mortality in COPD. Eur Clin Respir J 2014,1:24110. (PMID:26557244).

6. Öcal N, Doğan D, Taşkın G, Yıldız B, Özer S, Yamanel L. Continual assessment of mortality risk factors in geriatric patients hospitalized in intensive care due to pneumonia. Turkish Journal of Geriatrics 2016;19(1):1-8.

7. Dahl M, Vestbo J, Lange $P$, et al. C-reactive protein as a predictor of prognosis in chronic obstructive pulmonary disease. Am J Respir Crit Care Med 2007;175:250-5. (PMID:17053205).

8. Torres JP, Pinto-Plata V, Casanoua C, et al. C-reactive protein levels and survival in patients with moderate to very severe COPD. CHEST 2008;133:1336-43. (PMID:18339787).
9. Ranzani OT, Zampieri FG, Forte DN, Azevedo LC, Park M. C-reactive protein/albumin ratio predicts 90-day mortality of septic patients. PLOS ONE 2013;8(3):e59321.(PMID:23555017).

10. Fairclough E, Cairns E, Hamilton J, Kelly C. Evaluation of a modified early warning system for acute medical admissions and comparison with C-reactive protein/ albumin ratio as a predictor of patient outcome. Clin Med 2009;9:30-3. (PMID:19271597).

11. Mendy A, Forno E, Niyonsenga T, Gasana J. Blood biomarkers as predictors of long-term mortality in COPD. Clin Respir J. 2018;12:1891-9. (PMID:29227024).

12. Barnes PJ, Celli BR. Systemic manifestations and comorbidities of COPD. Eur Respir J 2009; 33(5):11651185. (PMID:19407051).

13. Landbo C, Prescott E, Lange P, Vestbo J, Almdal TP. Prognostic value of nutritional status in chronic obstructive pulmonary disease. Am J Respir Crit Care Med 1999;160(6):1856-61. (PMID:10588597).

14. Martinez FJ, Foster G, Curtis JL, Criner G, Weinmann G, Fishman A, et al. Predictors of mortality in patients with emphysema and severe airflow obstruction. Am J Respir Crit Care Med 2006 Jun 15; 173(12):1326-34. (PMID:16543549).

15. Marin JM, Cote CG, Diaz O, et al. Prognostic assessment in COPD: Health related quality of life and the BODE index. Respir Med 2011;105:916-21. (PMID:21282050).

16. Celli BR, Cote CG, Marin JM, et al. The bodymass index, airflow obstruction, dyspnea and exercise capacity index in COPD. New Eng J Med 2004;350:1005e12. (PMID:14999112).

17. Berry CE, Wise RA. Mortality in COPD: causes, risk factors, and prevention. COPD 2010;7:375-82. (PMID:20854053). 